(7)

\title{
Post 9/11 American Footprints in Pakistani Media: A Critique of Semiotic Discourses of Pakistani Newspapers
}

\author{
${ }^{a}$ Muhammad Akbar Sajid, ${ }^{\mathrm{b}}$ Sajid Waqar, ${ }^{\mathrm{c}}$ Rabia Mohsin, ${ }^{\mathrm{d}}$ Muhammad Javaid Jamil \\ ${ }^{a}$ Hod/ Assistant Professor NUML Multan Campus, Pakistan \\ ${ }^{\mathrm{b}} \mathrm{PhD}$ scholar, The Islamia University Bahawalpur, Pakistan \\ ${ }^{\mathrm{c}}$ Assistant professor, GOVt Emerson college Multan, Pakistan \\ ${ }^{\mathrm{d}}$ Lecturer Govt College Makhdoom Rasheed Multan, Pakistan
}

\begin{tabular}{|c|c|}
\hline ARTICLE DETAILS & ABSTRACT \\
\hline $\begin{array}{l}\text { History: } \\
\text { Accepted } 23 \text { March } 2020 \\
\text { Available Online } 31 \text { March } 2020\end{array}$ & $\begin{array}{l}\text { This paper highlights the power of image in shaping perception of the } \\
\text { people regarding post 9/11 American representation in Pakistani print } \\
\text { media discourses. The study deconstructs the semiotic discourse(s) of } \\
\text { Pakistani English newspaper Dawn (daily) from September } 2018 \text { to }\end{array}$ \\
\hline $\begin{array}{l}\text { Keywords: } \\
\text { Semiotics Discourses, American } \\
\text { Footprints, Representation, print } \\
\text { media, Semiological Discourse }\end{array}$ & $\begin{array}{l}\text { February } 2019 \text { to argue that linguistic and semiotic devices and } \\
\text { techniques work discursively to shape the readers' perception regarding } \\
\text { American foot-prints in Pakistani print media. It employs Multimodal } \\
\text { Critical Discourse analysis approach by drawing upon Machin (2007), }\end{array}$ \\
\hline Analysis & $\begin{array}{l}\text { Van Leeuwen framework for recontextualization (2008) and } \\
\text { Fairclough's (2003) for visual and linguistic analyses to lay bare }\end{array}$ \\
\hline $\begin{array}{l}\text { JEL Classification: } \\
H_{5} 6, L 82\end{array}$ & $\begin{array}{l}\text { embedded ideologies propagated through word-picture conjunction. The } \\
\text { levels of analysis include participants, settings, poses, objects, metaphor, }\end{array}$ \\
\hline DOI: $10.47067 /$ reads.v6i1.19o & $\begin{array}{l}\text { Inclusion, exclusion and discourse. Moreover, the researchers have } \\
\text { validated the findings of their semiotic analysis by conducting two } \\
\text { focus group discussions among the students of linguistics and other } \\
\text { disciplines. The findings reveal that print media semiotic discourses } \\
\text { provide an appropriate use of language in graphic form. The findings } \\
\text { reveal that no use of language is ideology free and words and pictures } \\
\text { work in conjunction to propagate desired ideology to the target } \\
\text { readership. Additionally, the study notices the visible change that has } \\
\text { taken place regarding American representation from superordinate to } \\
\text { back foot and ready-to-hold dialogue through semiotic discourses of } \\
\text { mentioned newspaper. }\end{array}$ \\
\hline
\end{tabular}

(C) 2020 The authors. Published by SPCRD Global Publishing. This is an open access article under the Creative Commons Attribution-

NonCommercial 4.0

Corresponding author's email address: masajid@numl.edu.pk

\section{Introduction}

Semiotics, having non verbal power, acts as meta-language (Jacobson, 1975). People usually regard their sense of sight more reliable than their sense of hearing. Hence, a signifier, in an iconic mode, provides a deeper understanding than the words can. Eco (1976) asserts that a picture speaks 
more than thousand words. Through semiotics, social and psychological human nature can be understood. A sign or gesture conveys meanings more emphatically. Sign is a trace, clue or mark which stands for both universality and individuality, says Barthes (1974). Saussure (1916) considers semiotics a science that studies life of signs in the society. Pierce (1931) concurs and states that semiotics is a system of principles to study behavior based on signs. Krestiva (1969) opines that every speech act conveys a message. It may be done through language of words, posture, gesture, clothing or any other means in a social context. Pierce and Saussure both presented models to explain semiotics. Although their models are different from each other in some respects, yet both lay stress on the semiotics as a more powerful means for imparting a specific ideology in the most effective manner. In Sussreran model, a sign is made up of signifier and signified whereas Pierce claims that an object produces 3 signs, i.e. icon, index and symbols. He called signifier as representamen, signified as interpretant whereas the third component of his model is object.

Both these models are based on semiotics which is a means of reflecting social reality that is culturally oriented and reflected through using certain devices in order to impart specific ideology and to shape individual's worldview. Moreover, semiology has rocketed in the present era because every individual can extract meaning from semiotic discourses according to his/her mindset. One thing significant about semiotics is that it is culturally oriented and carries a plethora of interpretations. Barthes (1974) argues that our senses are culturally trained to extract meanings from semiotics. Additionally, it is also an observed phenomenon that human beings not only convey verbally but also employ different techniques of communication other than verbal language. Still another significant feature of semiotic discourses is that with the help of word picture conjunction, and exploiting the technique of denaturalization of language, many explicit and implicit ideologies are propagated to the target audience.

\section{Semiotics: An influential genre of Pakistani news papers}

Newspapers are considered one of the best sites for ideological investment. Print media is considered one of the best ways to influence and shape the mind of masses. Hence, it plays a significant role in shaping the mindset of the target readership accordingly. Still imagery means a lot where the propagation of implicit ideologies is concerned. Political cartoons are regarded as communicative weapons. Boorstin (1963) asserts that the meaning does not come out obviously; it often exists lengthily and waits out to be disclosed. He argues that political cartoons have become more interesting than original and in fact have become the original. In today's world order, visuals are dominant images (Kress 1966). Political cartoons are a benighted ideology of realism. The way a cartoon is photographed, and where it is photographed, is a significant feature to be kept in mind while decoding semiotic discourse.

Print media discourses provide an insight into social, political and cultural reality of a society. They examine the role of language and visual language. They are an instrument of hegemony of political authority. Moreover, political cartoons have a two-fold appeal, i.e. reproduction of ideologies and voice of mainstream media. Semiotic discourse is a fast emerging domain of media discourses. It is one of the most influential ways of representation. Even the most ideologically packed incident can easily be unpacked through semiotic discourses, which in turn are decoded by different mindsets differently. The process of unpacking the political cartoons needs social, political and cultural knowledge because they are culturally oriented. Print media discourses serve as an active tool to propagate the ideology of the controlling group to the target audience. Like many forms of discourses, print media discourses (visual and linguistic) implicitly/explicitly represent the world view of the controlling ideological group. It is observed that same incident most often finds different 
representation(s) in accordance with the desires of controlling ideological group. Different representation of the same event is very common phenomenon in Pakistani print media. Both linguistic and visual techniques are employed to propagate desired ideology and worldview to the people to win general consent and to make them behave in the manner as desired by controlling ideological group. Therefore, print media linguistic \& semiotic discourses carry power within \& behind them. Zubair and Sajid (2012) assert that in Pakistani newspapers, visual structures have strong ideological and semantic dimensions with deep influence over the masses instead of being more formal pictures. Semiotics is context based and embodies various cultural connotations besides representing language in denaturalized way. Research Question is: How is America represented discursively through semiotic discourses of Daily Dawn?

\section{Methodology Employed}

Post 9/11 semiological representation of America has been through many phases. Most often, the concept of super-ordination and sub-ordination has been plaid up. In the recent past, the ideology of doing more has been asserted on Pakistan. This is how print media semiotic discourses have been representing Pak- US relationship and American foot prints in Pakistani print media in a dominating way. The present research critically decodes the semiotics carrying Pak-US relationship collecting data from Pakistani English Daily 'Dawn' to highlight whether any change has occurred in Pak-US relationship through semiotic discourses or not.

The data for the present research has been collected from Daily Dawn. Out of 25 political cartoons regarding American representation in Pakistani mentioned newspaper, one has been purposively selected to decode at linguistic and semiotic levels. In order to analyse the selected image, the researchers have employed Fairclough (2003) model of CDA, Kress and Van Leeuwen's (2006) for visual analysis have been applied to analyse the data at linguistic and semiotic levels. The researchers find this model apt for the analysis as it investigates social practices, events, ideologies and texts being shaped and reshaped by power relations within a social context. Furthermore, discourse analysis is a form of speech act analysis to find the social meanings using different techniques employed.

\subsection{Amended Model of Fairclough}

- Implicature

- representation

- assumption

- back/foregrounding

- Inclusion / exclusion

- Person as a State Metaphor

- Discourse as a social practice

- Use of Pronoun

\subsection{Amended Model of Kress and Leeuwen}

The rationale behind devising an amended model is that data for the present research comprises Linguistic and visual modes. In order to make semiotic analysis more valid, the researchers have also conducted Focus Group discussions on the selected images, concerning post 9/11 American foot print in Pakistani print media semiotic discourses. This has been done to counter the arguments that are usually leveled against semiotic analysis that most often it matches semioticians' specific way of decoding the images which, in certain cases, may not match with general perception on such texts. Two focus group discussions were held. The first group consisted of the students of M.Phil. linguistics studying at NUML Multan Campus. The other group included the participants from other disciplines like Education, 
Management Sciences, and Islamic Studies. Both the groups were of mixed gender and their age ranged from 25 to 50 years. Each Focus group discussion lasted for one hour and has been visually recorded. The levels which have been focused to analyze Focus Group discussion data are words, internal consistency, frequency, extensiveness and finding the big idea by employing Kruger's (2000) model for focus group data analysis.

Table 1 Devices Employed

\begin{tabular}{|ll|ll|}
\hline 1. & Gaze at the viewer & 1. & Demand \\
\hline 2. & Absence of the gaze at the viewer & 2. & Offer \\
\hline 3. & Close shot & 3. & Intimate / Personal \\
\hline 4. & Medium shot & 4. & Social \\
\hline 5. & Frontal angle & 5. & Impersonal \\
\hline 6. & Oblique angle & 6. & Involvement \\
\hline 7. & High angle & 7. & Detachment \\
\hline 8. & Low angle & 8. & Viewer Power \\
\hline 9. & High angle level & 9. & Equality \\
\hline
\end{tabular}

Figure 1

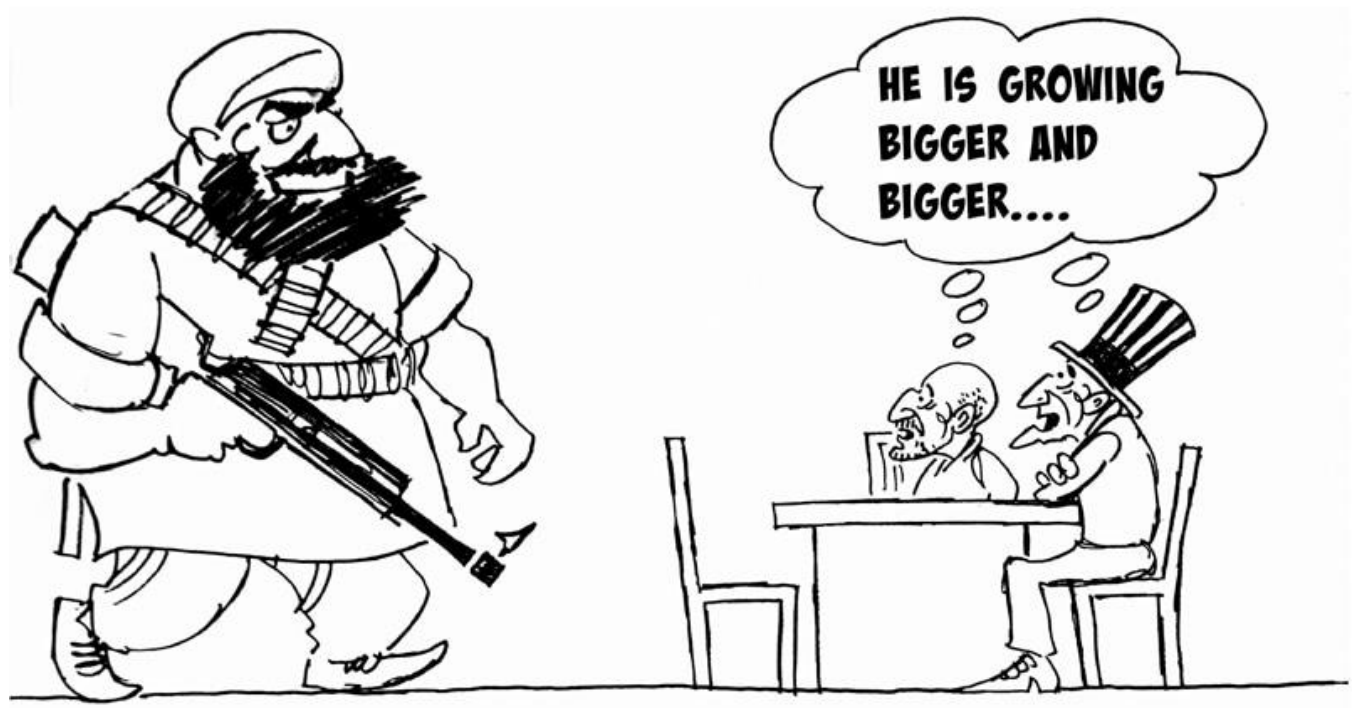

ZHWOR

\section{Linguistic and Semiotic Analysis}

Wodak (2001) states that discourses are historically rooted and most often they cannot be analyzed comprehensively without having the knowledge of context. Similarly, the semiotic discourse under analysis has different historical associations. In the past the Taliban's were under the thumb of America and hence, were provided and exploited as desired by the controlling master of that time (America). Philipson (1997) argues that power exists at various modalities and discursive modes of power are more influential as compared to coercive modes. Talibanized ideology slowly and gradually continued prevailing among them and among other groups in Afghanistan. Therefore, they have not only gained strength in size as is obvious from semiotic under analysis but in number as well because at present more than 54 percent area of Afghanistan is under the control of Talibans. This is how discursivity worked to win general consent in terms of number and power. Since the conquest of Russia these trained fighters were not handled judicially, In this way they continued gaining strength in terms of number, and material goods, they continued propagating their ideology among the masses and hence 
at present have gained so much discursive and coercive powers as has been illustrated in the semiotic under analysis to challenge America and Afghan Govt. Fairclough (2003) opines that media discourses reflect social reality. Similarly, the image under analysis illustrates that at present Talibans being so powerful are in a position to decide whether to hold peace talk with the other allies (Afghan Govt. \& America) or not. The semiotic under analysis illustrates that the way Talibans' representative is heading forward to the other allies (Afghan Govt. \& America) is very threatening. He is strongly built and well armed. He is heading forward towards the allies waiting for him to come and hold table talk with them as the language in graphic form (political cartoon) represents.

Moreover, another important thing to note is that both the allies as have been represented in the image are smaller in size as compared to the Taliban's representative marching towards them frowningly. This implies that the Talibans' representative is least interested in holding table talk rather in confrontation. As far as visual discourses are concerned different techniques are used in order to propagate message comprehensively. The semiotic under analysis carries the linguistic text written in capital letters bold font. This typographic technique is used when something very important is meant to be highlighted. The linguistic text written in capital letters and within the box in the form of speech bubbles connotes the only and ever-growing worry in the minds of American and Afghan presidents is ever increasing size of the Talibans by all means. The cartoonist of the controlling ideological group wants to convey a message in accordance with the Western perception and representation of stereotypical Muslim who is bearded and caped. One thing is also important to note that danger or terrorism has been associated with he, manhood. It is also a western perception especially about the bearded Muslims that they are no less than a threat terror to the west. If we look carefully at the end of the linguistic message the cartoon carries 'He is growing bigger and bigger....' there are four dots which stylistically are named as 'ellipses'. The use of ellipses (four dots) implies that the rest of the things have intentionally been left unsaid, presupposing that all the things are clear and well known to the participants.

Eco (2000) opines that word picture conjunction is a significant technique to enhance the effect of the message being propagated. Similarly, the ongoing action in the picture has been linguistically supported by present continuous "He IS GROWING....". Visually, this has been corelated by the representative of Talibans on his toes. Barthes (1974) argues that semiotic discourses are culturally oriented and carry plethora of information in them. This also holds valid because if the semiotic under analysis is decoded from western perspective it implies that Muslim militants are growing with every passing day and now, they have crossed the limits. All the efforts made by the West (America) are proving futile. The militant Talibans are least interested in holding talks, rather these attempts of restoring peace are unpleasant to them as is obvious from the face of the Muslim militant shown in the picture. This is how the West supports its stance that the East (Muslims) are the embodiment of evil and danger to the civilized west.

On one hand there is a concept of growing. The use of word growing implies one thing more important is that growing is used for living beings. Living beings have the capability of growing. It is pertinent to mention here that the Talibanized ideology has been growing since its inception. Ideology is regarded as a living being as it can drive the living beings. The astonished faces of American and Afghan presidents illustrate that the Talibans have gained strength beyond their expectations. Hence, both are terribly afraid. The nearer the Talibans' representative is coming, the more afraid they are getting. Another important point to notice as highlighted by the semiotic under analysis is that the Afghan president seems more frightened as compared to the American president. His foot prints are invisible the way he is sitting on the chair. 
Still another, feature of the use of bigger is the use of comparative degree which when correlated with the size of the person is bigger as compared to the other two persons as mentioned in the image. One of them is the representative of America and the other is the representative of Afghan presupposedly. If the sizes of the two persons are combined, they cannot be compared even with the single size of the bearded person who is alleged as a terrorist. This implies that despite the combined efforts of American and Afghan governments are unable to crush the Talibanized ideology. Still another visual technique that has been employed here is that the person is approaching towards the chair vacant for him from the back side of the chair. Moreover, empty chair at the left side of the table also implies that the other party that is involved in the talk is not responding to the arguments or discussion. Moreover, one important thing is the size of the chair, the person is approaching to sit on seems too small as compared to the size of the person the chair is vacant for. It also implies that the Taliban representative is from the way he is being entertained in the upcoming session of dialogue among the three parties. It seems that he is not comfortable with the terms and conditions on which the other parties are ready to hold discussion. One the implications might be as connoted by the small size of the empty chair that the demands of the Taliban representative are as huge as his size is and he will be uncomfortable even if he sits at the dialogue table because of the too small size of the chair. This situation implies that although the three parties have been holding talks for sometimes yet not in accordance with the demands of the Talibans. Therefore, the representative of Taliban is angry and perhaps he has made up his mind that things are not going to be settled through talks rather with gun as is illustrated by the style with which he is approaching towards them.

Still another important feature to be noticed is the dress code, the person having the gun in his hand is wearing a shalwar-qameez, turban with bearded get up which is most of the time is associated with Muslim clergy man. According to western stereotypical perception about rigid and hardliner Muslims, they are extremist and are least inclined in embracing any type of change in the form of dialogues initiated by the peace-loving west. Moreover, the west perceives that such type of Muslims are so rigid and close minded as is highlighted by tightly sealed turban. The west perceives that the hardliner Muslims get the heat of extremism from the fundamentals of Islam and finally explode them in the form of suicide attackers. They are so much under the influence of violent ideology that they are least inclined to listen to others. They picture under analysis illustrates that the earholes of the Muslim / Taliban representative are almost closed, therefore, he is not ready to listen to others because he is totally being driven by his violent ideology. Rather he is fully inclined in doing whatever he has been fed-up with. The concept of persons as state metaphors has also been highlighted here. The three persons mentioned in the pollical cartoon respectively stand for their countries or school of thought. The American president as shown in the picture in sitting with flat footing which implies that up to a great extent, he is on backfoot. In the past it was observed that America has continuously been following the ideology of "Doing More" from the Taliban and Pakistani government, but the present image illustrates the change in political scenario that has taken place has forced America to be on back foot. Because of so many social political, geographical and economic factors, America has realized that holding talk may prove more beneficial than deciding things with coercive force.

Still another significant feature of the image under analysis is the boggled face of Afghan President which implies that he is absolutely worried about his future because after the withdrawal of American forces (if possible) and handing over rule to Taliban, he would have no ground to stand on as is obvious from the picture that his footprints are not visible. Kress (2010) argues that Cartoons are regarded as metaphorical representations of speech bubble; the two small speech bubbles on the hat of American President imply the thoughts in his mind that how to deal Afghan government and Taliban 
in such a troubling situation. Whereas, the three small speech bubbles on the head of Afghan President imply that he is more worried about his survival. If the things are settled between Taliban and American what would be his or present government's status. Still another important thing that has been shown in this image is that American president is wearing a flag of his country on his hat which implies that America has an identity of her own ; on the other hand Afghani president is bare headed which means he does not have any peculiar identity. At the same time his survival is at the risk. One of the implicatures may be that because of the destruction caused by terrorism, Afghanistan and the Afghan governments have totally lost their control and they are totally under the thumb of America and perhaps this might be the cause of their losing identity. Hence the overall image that appears after going through the linguistic and semiotic discourse is the political scenario regarding the America, Afghan government and the Talibans is very much vague till now. On one hand America with her allies is doing her best to restore peace and to abolish terrorism yet on the other hand despite doing their best the terrorism or the Muslim fanaticism is growing bigger and bigger as has been shown at linguistic and semiotic level. So the underlying message that the image suggests is that America is the representative of the civilized world and peace whereas, Muslim militants, especially the Talibans have been represented as anti to all the peace restoring forces. This is a message to the rest of the world America- Talibans dialogue are not going to get the desired results very soon because both are sticking to their deep-rooted ideologies. In this way Fairclough's (2003) claim seems justified that print media discourses are considered as one of the best sites for the ideological investment. So, the ideology that has been invested through the linguistic and semiotic discourses is that despite doing best America and the other allies, so far have not been able to come to restore the peace and so far have not been able to come to good terms to other parties because peace cannot be had with the gun rather it can be had with the dialogues. So, here we see two sides of the image, American and Afghani presidents are waiting for the peace talk whereas the Muslim militant / Taliban have been shown least inclined in holding dialogue with them rather they seem more willing to confront, it seems perhaps they have decided that things are not going to be settled with carrot rather with stick as is connoted by the get-up of the Taliban representative because he is marching towards America and Afghan presidents with rolled selves and finger at the trigger of the gun.

\section{Focus Group Findings}

As mentioned earlier in the methodology section the researchers have validated the findings of semiotic analysis through the remarks of focus group participants' remarks. The remarks of some of the participants have been included to support the stance. One of the focus group Participants while expressing her ideas on the semiotic under analysis said:

"Post 9/11 media representation of America implies that perhaps America has failed in reaping her interests in Afghanistan. The picture represents a changing scenario showing, America unable to handle Taliban.”

Another participant remarks as:

"The picture is meta-narrative. The chairs on which American \& Afghan presidents are sitting are unarmed whereas the man coming to hold dialogue the two presidents is fully armed. Here the concept of unarmed chair and armed man has been juxtaposed. Interestingly, the unarmed chair is Vacant for the armed man".

One of female participants remarked as under: 
"The political cartoon embodies different counter narratives. The three men in the picture are representatives of three different ideological groups.”

Fairclough (2003) opines that language connotes and denotes. The counter narratives have been portrayed. According to the participants that apparently, the representative of the Talibans has been shown unwilling to hold dialogue but inwardly the American president is also unwilling to hold talk. This is a mere a show of. The Talibans are the product of America. This is how the Linguistic \& Semiotic discourses are connoting and denoting things simultaneously. Hence, visuals carry bundle of interpretations.

Another participant remarked;

"The way guy (representative of Taliban) is approaching towards them is astonishing to both American and Afghan president because perhaps his style is totally unexpected to them and hence, they are astonished."

The overall picture that emerges after analyzing the remarks of the participants is that the previously trained or in Asian context the Badmash or the Terrorists/Talibans, who were beneficial for America, now have gone beyond her control. It means that Taliban and American are in direct contact or in direct clash with each other. Afghani President is just like a Harbinger between them. Irony of fate is that America is going to settle the issue with NATO forces, still trying to control the fate of the country. America is showing to the world that she is most concerned about the terrorist situation in Afghanistan. The participants concluded their remarks that America has been trapped in her own evil design. Now the talibanised ideology will continue increasing and there will be increase in their number with every passing day as is obvious from the picture. In this way the researchers validated their findings of semiotic analysis through focus group discussions.

\section{Conclusion}

The present research concludes that an obvious change is there regarding American representation through Pakistani Print Media semiotic discourses i-e a shift from super-ordinate position to back foot (ready to hold talk). In the past, it was observed that America was represented as dominant and Pakistan and Talibans as dominated, through print media discourses but the findings of the present research reveal that power paradigm shift is obvious. Now print media representations of America through semiotic discourses is different in a sense that America has been represented as ready to hold talk instead of imposing her authority on Pakistan/Afghanistan. Still another significant finding of the research is that semiotic discourses are significant genre of print media and word-picture conjunction works a lot in shaping the mindset of the target audience. The way she (America) has been represented through the semiotic discourses of Pakistani print media is that America seems moving at back foot, ready for negotiation. The percentage of such data showing America on back foot and instead of asserting her super- ordination is ready to hold talk to resolve political issues. Hence, the present research concludes that print media semiotic discourses on one hand shape the mindset of its readers and on the other hand represent political changes taking place in the global scenario. The impact of political cartoons on the people in the back drop of Pak- Us relation is of vital significance.

\section{References}

Barthes. R (1974). Muthologies. New York: Wang.

Eco, U. (1976). A Theory of Semiotics. Bloomington: Indiana University Press.

Jackobson, R. (1975). Coupdel'oeilsur le Development de la Semiotique. Studies in Semiotics. 
Bloomigton: Indiana University Press.

Kress, G. \& Leaween, V. T. (2006). Reading Images: The Grammar of Visual Design. 2nd Ed. London: Routledge \& New York. Peirce.

Kristeva, J. (1969). Semiotic. Researches Pour Une Semanalyse. Paris: Seuil.

Perice, C. (1931-58). Collected Papers of Charles Sanders Peirce, Vol 1-8, C. Hartshome \& P. Weiss (Eds.). Cambridge \& Mass: Harvard University Press.

Kress, G. (2010), Multimodality: A Social Semiotic: Approach to Contemporary Communication. London: Routeledge.

Saussure, F.de. (1916). Course de Linguistique Generale. Paris:Payot.

Fairclough, N. (2003). Analysing Discourse: Textual Analysis for Social Research. London: Routledge.

Peirce, C. S (1931- 58). Collected Papers of Charles Sanders Peirce, vol 1-8. C. Hartshorne and P. Weiss (Eds.) Cambridge, Mass: Harvard University Press.

Phillpson, R. (1992). Linguistic Imperialism. Oxford: Oxford University Press.

Wodak, R. (1996). Disorders of discourse. London: Longman.

Zubair, S. (2006). Women, English Literature and Identity Construction in Southern Punjab. Pakistan Journal of South Asian Development. 1(2) 249-271.

Boorstin, D. J. (1964). The image: a guide to pseudo-events in America, USA, Harper \& Row.

Sajid, M. A. (2012). Representations of Islam: A Study into the Discourse of Pakistani and Western Newspapers. Bahauddin Zakariya University, Multan, Punjab, Pakistan 